[19] Soukoulis, C., Gaiani, C., Hoffmann, L. (2018). Plant seed mucilage as emerging biopolymer in food industry applications. Current Opinion in Food Science, 22, 28-42. doi: http://doi.org/10.1016/j.cofs.2018.01.004

[20] Touré, A., Xueming, X. (2010). Flaxseed Lignans: Source, Biosynthesis, Metabolism, Antioxidant Activity, Bio-Active Components, and Health Benefits. Comprehensive Reviews in Food Science and Food Safety, 9 (3), 261-269. doi: http:// doi.org/10.1111/j.1541-4337.2009.00105.x

[21] Marpalle, P., Sonawane, S. K., Arya, S. S. (2014). Effect of flaxseed flour addition on physicochemical and sensory properties of functional bread. LWT - Food Science and Technology, 58 (2), 614-619. doi: http://doi.org/10.1016/j.lwt.2014.04.003

[22] Marpalle, P., Sonawane, S. K., LeBlanc, J. G., Arya, S. S. (2015). Nutritional characterization and oxidative stability of $\alpha$-linolenic acid in bread containing roasted ground flaxseed. LWT - Food Science and Technology, 61 (2), 510-515. doi: http://doi. org/10.1016/j.lwt.2014.11.018

[23] Pourabedin, M., Aarabi, A., Rahbaran, S. (2017). Effect of flaxseed flour on rheological properties, staling and total phenol of Iranian toast. Journal of Cereal Science, 76, 173-178. doi: http://doi.org/10.1016/j.jcs.2017.05.009

[24] Drobot, V. I. (Ed.) (2015). Tekhnokhimichnyi kontrol syrovyny ta khlibobulochnykh i makaronnykh vyrobiv. Kyiv: NUKhT, 948.

[25] Lebedenko, T. Ie., Pshenyshniuk, H. F., Sokolova, N. Iu. (2014). Tekhnolohiia khlibopekarskoho vyrobnytstva. Praktykum. Odessa: «Osvita Ukrainy», 392.

\title{
STUDY OF QUALITY AND SAFETY PARAMETERS OF LIVER PASTES WITH AUBERGINE POWDER
}

\author{
Oksana Dzyundzya \\ Department of hotel and restaurant and tourist business \\ Kherson State University \\ 27 Universitetska str., Kherson, Ukraine, 73000 \\ Dzokvaok@gmail.com \\ Valentyna Burak \\ Department of Food Engineering \\ Kherson State Agricultural University \\ 23 Sretenskaya str., Kherson, Ukraine, 73006 \\ Irina Ryapolova \\ Department of Food Engineering \\ Kherson State Agricultural University \\ 23 Sretenskaya str., Kherson, Ukraine, 73006 \\ Nadiia Voievoda \\ Department of Food Engineering \\ Kherson State Agricultural University \\ 23 Sretenskaya str., Kherson, Ukraine, 73006

\section{Mariya Shinkaruk} \\ Department of Food Engineering \\ Kherson State Agricultural University \\ 23 Sretenskaya str., Kherson, Ukraine, 73006
}




\author{
Artem Antonenko \\ Department of hotel-restaurant business \\ Kyiv University of Culture \\ 36 A Konovaltsia str,. Kyiv, Ukraine, 01133 \\ artem.v.antonenko@gmail.com
}

Tetiana Brovenko

Department of hotel-restaurant and tourist business

Kyiv National University of Culture and Arts

36 Konovaltsia str., Kyiv, Ukraine, 01133

Myroslav Kryvoruchko

Department of engineering and technical disciplines

Kyiv National University of Trade and Economics

19 Kioto str., Kyiv, Ukraine, 02156

Galina Tolok

Department of hotel-restaurant and tourist business

Kyiv National University of Culture and Arts

36 Konovaltsia str., Kyiv, Ukraine, 01133

Vitalii Mihailik

Department of technology and restaurant establishment organization

Kyiv National University of Trade and Economics

19 Kyoto str., Kyiv, Ukraine, 02156

\begin{abstract}
The aim of this work is to study quality and safety parameters of developed recipes of liver pastes with a partial replacement of liver by aubergine powder that allows to improve their food value and to introduce them in food rations of people, working at toxic enterprises, living on ecologically polluted territories and all population layers.

This work is devoted to studying quality and safety parameters of liver pastes with aubergine powders, produced by infrared drying at temperature $50-60{ }^{\circ} \mathrm{C}$. Chemical parameters, established for developed paste products, are presented.

The use of aubergine powders gives a possibility to increase biological and food values, to widen the assortment of pastes with prognosticated quality parameters, to form new consumption properties of products, to use the food potential of vegetable supplements more completely. It has been proved, that new pastes with using aubergine powders confirmed advantages of developed products over traditional ones.

New products have a balanced chemical composition, low energetic value, decreased content of easily assimilated carbohydrates and increased content of healthy ingredients of functional and treating-prophylactic destination.

These studies testify the quality and safety of developed paste recipes. It has been established, that adding aubergine powders in paste recipes results in increasing a food value at the expanse of raising an amount of carbohydrates, content of irreplaceable amino acids, enrichment with mineral substances and vitamins.
\end{abstract}

Keywords: aubergine powders, paste, quality, safety.

DOI: $10.21303 / 2504-5695.2019 .00956$

\title{
1. Introduction
}

Special attention is paid to the creation of qualitatively new food products, enriched with biologically active substances, able to correct metabolic processes in the human organism, to raise its protective functions, to decrease a development risk of different diseases. That is why production of food products of special destinations, satisfying physiological needs of the human organism, having at the same time treating and prophylactic purposes, is urgent for food industry $[1,2]$. 
The quality of food products depends of many factors. Thus, for example, a food value of products depends on content of proteins, fats, carbohydrates, mineral substances and vitamins in them. Their biological value is determined by the quality of proteins, especially irreplaceable amino acids, their ratio, speed of attacks by different enzymes, presence of anti-nutritive substances. In a wider understanding a biological value provides other essential substances - polyunsaturated fatty acids, mineral elements, vitamins and so on in a product. So, one of important stages of combined food products development is a study of their chemical compositions and comparison with ones of traditional analogues.

Among different groups of food products the essential share belongs to dishes of meat, meat products and subproducts. Paste is a universal product of high demand that is a homogenized protein-fatty food system. The production technology of pastes allows to transform subproducts in healthy food, accessible for everyone. The classic recipe of liver pastes includes subproducts, milk products and vegetable raw materials. It is possible to produce pastes of different products in different combinations [3]. The delicate consistence of pastes is achieved at the expanse of special ways of raw materials processing and accurate selection of ingredients. Their food value is increased as a result of combining recipe components that contain both vegetable and animal raw materials. The combination of different elements allows to create products, enriched not only with animal proteins, but also biologically active substances (food fibers, vitamins, macro- and microelements) [1].

Among products, made at food industrial enterprises and restaurant economy institutions, the essential share belongs to ones of paste mass, produced of beef or poultry liver with adding chicken broth, egg mass or blend, cow butter, taste and aromatic substances. But the absence of functional effects in products restrains their wide production and consumption [4, 5].

One of ways of solving a problem of creation pastes of special destination is the use of ecologically safe non-traditional supplements of vegetable origin, especially powders of aubergine fruits that maximally preserve the nutrient composition and are a source of pectin substances, cellulose, macro- and micronutrients $[6,7]$.

An important task of modern technologists is to create food products, high-quality, safe and accessible for the wide circle of consumers, providing physiological needs of the organism. Because the main factor determining human health is full-value nutrition. It is known, that the Ukrainian population suffers from the deficit of micronutrients in food. In this regard it is important to provide vitally important substances to products of special destination with a balanced chemical composition, enriched with proteins, food fibers, microelements, vitamins and so on [1, 8-14].

This work takes into account main development directions of food industry, based on increasing the biological value of dishes and minimizing material and energetic losses. It is important, because tasks on providing the population with food products, corresponding to physiological needs and requirements of balanced nutrition and realizing the directed influence of the metabolic background of the organism, are solved $[1,15]$.

The closest (control) to the offered one is a traditional way of preparing pastes [3], that includes: preparation of raw materials, comminution of beef liver, melting of cream butter, shaking of all components by a mixer, pouring in a form and baking. But a shortcoming of this way is an unbalance of the chemical composition, insufficient amount of microelements and vitamins, organoleptic parameters need perfection, namely: color, consistence, plasticity improvement. The main component is beef liver, which shortcoming is the essential amount of purines, urinary acid and cholesterol [2]. At the same time, as a result of the great amount of acid radicals in liver, the acid-alkaline balance in the organism shifts to the acid side. It provokes metabolic disorders, favors earlier ageing of the organism that is why it is expedient to add vegetable raw materials to the recipe for normalizing acidity and improving digestibility of liver by the organism. Taking it into account, 50 $\%$ of beef liver was replaced by chicken one that has high consumption properties and is essentially cheaper, comparing with beef. The main source of easily assimilated carbohydrate in the control recipe was bread, excluded from the recipe and replaced by the additional amount of liver.

The improved technology is based on the task to improve food and biological values of pastes, to give them functional properties at the expanse of decreasing their caloric content, balancing their amino acid and mineral composition. 
The set task is solved by the way of preparing pastes, at which in the process of technological development the part of beef liver (5\%) is replaced by aubergine powder.

The aim of this work is to study quality and safety parameters of developed recipes of liver pastes with a partial replacement of liver by aubergine powder that allows to improve their food value and to introduce them in food rations of people, working at toxic enterprises, living on ecologically polluted territories and all population layers.

\section{Materials and methods}

Research objects in the work are two samples of ready pastes. A control sample is a liver paste, produced by traditional technology [3]. An experimental sample includes $5 \%$ of aubergine powder together with the main components.

The amount of beef, included in the liver paste recipe, is $(\mathrm{g})$ : beef liver - 31.6; chicken liver - 31.6; cream butter (72 \%) - 17.5; eggs - 11.0; milk (1.0\%) - 7.5; salt - 1.1; black pepper - 0.02 . Aubergine powder was introduced in amount $5 \%$ of the beef liver mass.

Table 1 presents the organoleptic parameters of aubergine powders $[6,7]$

Table 1

Organoleptic parameters of aubergine powders

\begin{tabular}{cl}
\hline Parameter & \multicolumn{1}{c}{ Powder characteristic } \\
\hline Outlook & Powder-like mixture, homogenous, without side admixtures, easily soluble clots are permitted (Fig. 1) \\
Consistence & Homogenous \\
Dispersion & $<0.5 \mathrm{~mm}$ \\
Color & From light-brown to brown \\
Smell & Inherent to this dry raw material, without side smells \\
Taste & Smack of dry raw material, obtained powder without side admixtures
\end{tabular}

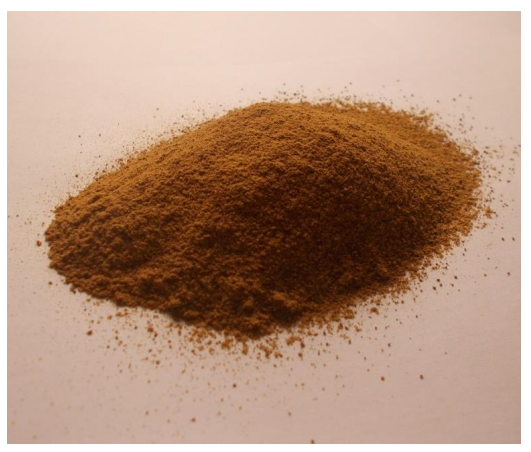

Fig. 1. Aubergine powder [6]

The devices for conducting the experiments are presented on Fig. 2.

Based on the previous experimental studies of the structural-mechanical properties of the semi-product, there was obtained the value of shift tension $\theta$ (D) and mixture viscosity $\eta$ (D) depending on shift speed D, established the water-retaining, water-binding and emulsifying capacities. The organoleptic parameters of semi-products of paste lines masses were studied, namely: consistence, outlook, color and smell. Taking into account the obtained data, there was determined the rational amount of aubergine powder as $5 \%$ by mathematic methods, based on the change of the complex quality parameter as a result of the supplement content.

Based on the structural-mechanical and organoleptic properties of semi-products of paste liver masses, it has been established, that introduction of $5 \%$ of aubergine powder is the optimal.

For studying the quality and safety of pastes, organoleptic and microbiological parameters were determined, the chemical composition of the ready product was studied. 


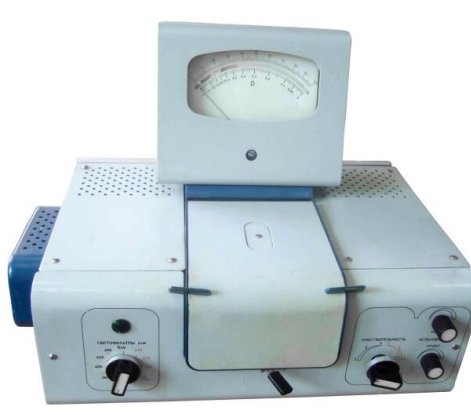

$a$

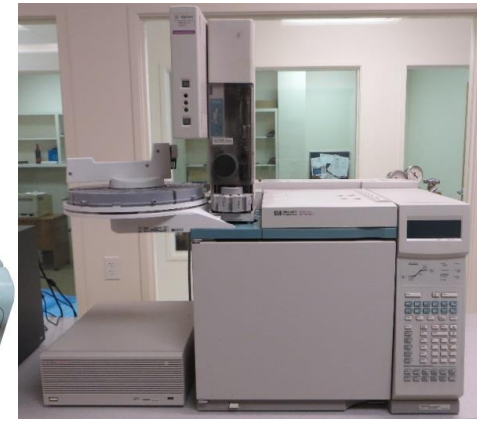

b

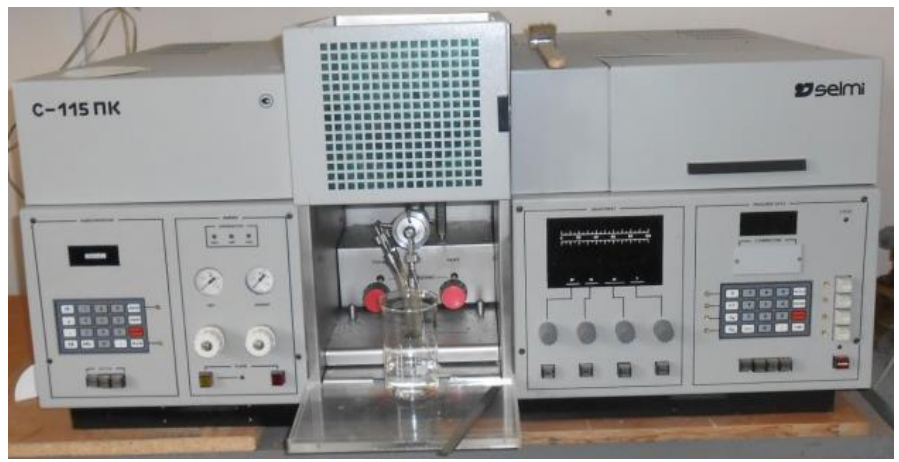

$c$

Fig. 2. Devices for conducting the experiments: $a$ - photocolorimeter CPC-2

(“Zagorsk optical-mechanical plant”, Russia); $b$ - gas chromatograph HP 6890 («Hewlett Packard», USA; $c$ - spectrophotometer S-115 PC (PC «Electron», Ukraine)

For obtaining the reliable values of experimental data, all studies were conducted no less than trice, making two parallel determinations at each experiment.

Taking of samples for the organoleptic and physical-chemical studies and their preparation for the analysis was conducted according to requirements of SSU 4823.2:2007 [16]. The main quality parameters of liver pastes, determined at the estimation, include: outlook, look in the cut, color, consistence, smell and taste.

Moisture was determined by drying to the constant mass at temperature $105^{\circ} \mathrm{C}$ according to SSU $4910: 2008$ [17].

Mass share of ash, insoluble in the solution with mass share of saline acid $10 \%-$ by wet ashing of a sample in nitrogen acid and burning it in the electric stove according to SSU 4672:2006 [18].

Protein mass share was determined by Kjeldahl method. It is based on mineralization of a sample by Kjeldahl, removal of ammonia in the sulfuric acid solution with further titration of the studied sample [19].

Fat mass share was determined by the method, based on multiple fat extraction from a dried batch by volatile solvents with further removal of a solvent and drying of an extracted sleeve to the constant mass. Extraction was realized in Soxhlet apparatus, hexane was used as a solvent [20].

Fatty-acid composition of pastes - by the method of gas chromatography on the gas chromatograph HP 6890 [21].

Mineral composition - was determined by the method of atomic-absorption spectrophotometer by the atomic-absorption spectrophotometer S-115 PC [22].

The food value parameters are presented in recalculation for $100 \mathrm{~g}$ of the edible part of the product, at that the content of proteins, fats and carbohydrate is expressed in grams.

The calculation of the food and energetic value was conducted by calculating method [23]. 


\section{Experiments}

At the experiments there was improved the technological process of pastes with vegetable supplements, consisted of the following operations: preparation of raw materials, preparation of the semi-product of paste mass, forming and baking of a dish.

Preparation of the raw materials for production

Liver is washed, dried, cleaned and cut in pieces. Chicken eggs are processed according to "Sanitary rules" [15, 24].

Preparation of the semi-product of paste liver mass

Prepared liver is comminuted in the meat chopper. At solvent temperature $45 \ldots 60{ }^{\circ} \mathrm{C}$ aubergine powder is restored, the swelling duration is $10-15$ min. Comminuted liver is added with the restored powder, cooled to temperature $8 \ldots 10^{\circ} \mathrm{C}$, cream butter, milk, eggs, salt, spices. Then the whole this mass is homogenized on the cutter $\left(\tau=10 \ldots 15 \mathrm{~min} ., \mathrm{n}=4000 \ldots 4500 \mathrm{~s}^{-1}, t=10 \ldots 12^{\circ} \mathrm{C}\right)$.

Forming

The ready semi-product is poured in forms.

Baking

The baking duration is $50-60 \mathrm{~min}$ at temperature $180-190{ }^{\circ} \mathrm{C}$.

The used method of producing pastes with aubergine powders gives the new technological result: allows to get a dish with a balanced chemical composition, increased content of vitamins, macro- and microelements and food fibers. The social effect from implementation of developed products is in providing the population with special nutritive products of an increased food value.

\section{Results}

The general chemical composition of the developed pastes is presented in Table 2.

Table 2

General chemical composition of the developed pastes

\begin{tabular}{|c|c|c|}
\hline Parameter name & Paste control & Paste experiment \\
\hline 1 & 2 & 3 \\
\hline Mass share of moisture, $\%$ & $64 \pm 0.1$ & $58 \pm 0.1$ \\
\hline Mass share of protein, $\%$ & $12.4 \pm 0.1$ & $12.4 \pm 0.1$ \\
\hline Mass share of fat, $\%$ & $15.4 \pm 0.1$ & $16.0 \pm 0.1$ \\
\hline Omega-3 fatty acids, $g$ & $0.1 \pm 0.01$ & $0.1 \pm 0.01$ \\
\hline Omega-6 fatty acids, $g$ & $0.7 \pm 0.02$ & $0.7 \pm 0.03$ \\
\hline Cholesterol, mg & $286.2 \pm 0.01$ & $260.4 \pm 0.1$ \\
\hline Mass share of carbohydrates, $\%$ & $6.6 \pm 0.1$ & $2.3 \pm 0.1$ \\
\hline Food fibers, $g$ & $0.01 \pm 0.1$ & $0.03 \pm 0.1$ \\
\hline Starch and dextrins, $\mathrm{g}$ & $5.187 \pm 0.001$ & Footprint \\
\hline Mass share of ash, $\%$ & $1.361 \pm 0.001$ & $1.917 \pm 0.001$ \\
\hline Caloric content, $\mathrm{kcal} / 100 \mathrm{~g}$ & $212.8 \pm 0.1$ & $202.8 \pm 0.1$ \\
\hline \multicolumn{3}{|c|}{ Mineral composition } \\
\hline $\mathrm{Na}, \mathrm{mg}$ & $196.08 \pm 0.01$ & $429.03 \pm 0.01$ \\
\hline $\mathrm{K}, \mathrm{mg}$ & $198.24 \pm 0.01$ & $188.31 \pm 0.01$ \\
\hline $\mathrm{Ca}, \mathrm{mg}$ & $30.03 \pm 0.01$ & $28.44 \pm 0.01$ \\
\hline $\mathrm{Mg}, \mathrm{mg}$ & $13.96 \pm 0.01$ & $14.30 \pm 0.01$ \\
\hline $\mathrm{P}, \mathrm{mg}$ & $216.90 \pm 0.01$ & $194.30 \pm 0.01$ \\
\hline
\end{tabular}


Continuation of Table 2

\begin{tabular}{|c|c|c|}
\hline 1 & 2 & 3 \\
\hline $\mathrm{Fe}, \mathrm{mg}$ & $4.29 \pm 0.01$ & $7.19 \pm 0.01$ \\
\hline $\mathrm{Zn}, \mathrm{mg}$ & $2.90 \pm 0.01$ & $0.95 \pm 0.01$ \\
\hline $\mathrm{Mn}, \mathrm{mg}$ & $0.209 \pm 0.003$ & $0.185 \pm 0.002$ \\
\hline $\mathrm{I}, \mathrm{mcg}$ & $2.84 \pm 0.01$ & $4.41 \pm 0.01$ \\
\hline Se, mcg & $26.33 \pm 0.01$ & $29.87 \pm 0.01$ \\
\hline $\mathrm{Co}, \mathrm{mcg}$ & $12.55 \pm 0.01$ & $10.49 \pm 0.01$ \\
\hline Mo,mcg & $64.02 \pm 0.01$ & $48.75 \pm 0.01$ \\
\hline \multicolumn{3}{|c|}{ Vitamin composition } \\
\hline Retinol, mg & $4.75 \pm 0.01$ & $5.77 \pm 0.01$ \\
\hline $\mathrm{B}_{1}, \mathrm{mg}$ & $0.188 \pm 0.01$ & $0.236 \pm 0.01$ \\
\hline $\mathrm{B}_{2}, \mathrm{mg}$ & $1.325 \pm 0.01$ & $1.275 \pm 0.01$ \\
\hline $\mathrm{B}_{4}, \mathrm{mg}$ & $393.55 \pm 0.01$ & $260.23 \pm 0.01$ \\
\hline $\mathrm{B}_{6}, \mathrm{mg}$ & $0.412 \pm 0.01$ & $0.467 \pm 0.01$ \\
\hline $\mathrm{B}_{9}, \mathrm{mg}$ & $138.66 \pm 0.01$ & $135.38 \pm 0.01$ \\
\hline $\mathrm{B}_{12}, \mathrm{mcg}$ & $34.18 \pm 0.01$ & $21.34 \pm 0.01$ \\
\hline PP, mg & $8.00 \pm 0.01$ & $7.84 \pm 0.01$ \\
\hline $\mathrm{E}, \mathrm{mcg}$ & $58.18 \pm 0.01$ & $29.25 \pm 0.01$ \\
\hline
\end{tabular}

As it is testified by the data of Table 2, the developed paste has a series of advantages, comparing with the control, from the point of view of food and biological value that are: in decreasing the caloric content, enrichment with such functional ingredients as polysaccharides of non-starch nature.

It has been established, that the caloric content of the developed paste decreased by $5 \%$. The analysis of the vitamin and mineral composition of the developed products proved the biological value increase (Table 2). It has been established, that the content of vitamin $\mathrm{B}_{1}$ in the paste with aubergine powder increased by $25 \%$, vitamin $\mathrm{B}_{6}-$ by $13 \%$. But the decrease of amounts of other vitamins doesn't essentially influence the quality of the developed products, because it satisfies the daily need, namely biotin $-58 \%$, choline $-52 \%$, riboflavin $-70 \%$, nicotine acid $-39 \%$.

It has been established (Table 2), that the sodium content in the developed pastes increased in 2.2 times, iron - by $71 \%$, selenium - by $13.2 \%$.

The content of fat in the experimental sample increased by $4 \%$, but the ratio between omega- 3 and omega- 6 remained stable (1:7), and the content of cholesterol decreased by $9 \%$.

The protein content in paste samples remained stable, but it is possible to make conclusions about changes of the biological value of the products in one or another way only after studying the amino acid composition, because the biological value is determined, first of all, by the qualitative composition of protein (Fig. 3).

The analysis of the amino acid composition of the pastes (Fig. 3) established, that the total amount of irreplaceable amino acids in the developed recipe is by $12,6 \%$ more, comparing with the control.

One more important quality parameter is safety of pastes. The microbiological parameters of the studied samples of the products were studied (Table 3). 


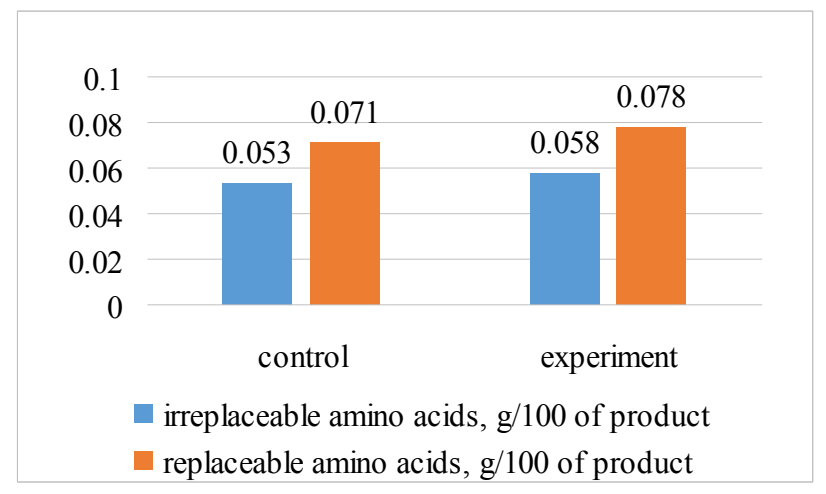

Fig. 3. Amino acid composition of the developed pastes

Table 3

Microbiological studies of the paste with aubergine powder

\begin{tabular}{|c|c|c|c|c|}
\hline \multirow{3}{*}{ Name of determined parameters } & \multicolumn{4}{|c|}{ Values of determined parameters } \\
\hline & \multirow{2}{*}{$\begin{array}{l}\text { According to } \\
\text { requirements of } \\
\text { SSU 4432:2005 }\end{array}$} & \multicolumn{3}{|c|}{ Obtained values, days } \\
\hline & & 1 & 3 & 5 \\
\hline $\begin{array}{l}\text { Number of mesophilic aerobic and facultative-anaerobic } \\
\text { microorganisms, CFU/g, no more }\end{array}$ & $1.0 \times 10^{3}$ & $1.0 \times 10^{2}$ & $2.3 \times 10^{2}$ & $1.3 \times 10^{3}$ \\
\hline $\begin{array}{l}\text { Bacteria of colon bacillus group (coliforms), } \\
\text { in } 0,1 \mathrm{~g} \text { of product }\end{array}$ & Not permitted & Not revealed & Not revealed & Not revealed \\
\hline $\begin{array}{l}\text { Pathogenic microorganisms, including bacteria of } \\
\text { Salmonella generis, in } 25 \mathrm{~g} \text { of product }\end{array}$ & Not permitted & Not revealed & Not revealed & Not revealed \\
\hline Sulphite reducing clostridia in $0.1 \mathrm{~g}$ of product & Not permitted & Not revealed & Not revealed & Not revealed \\
\hline
\end{tabular}

The results of the microbiological studies testified the high quality and safety of the product, because the parameters are within the norm, namely MAFAnM at the third day are $2.3 \cdot 10^{2} \mathrm{CFU}$ at permitted norm $1.0 \cdot 10^{3} \mathrm{CFU}$.

The organoleptic parameters were established by the method of sensor analysis of the studied samples of the paste product. The expert group included 6 persons, whose sensor sensitivity had been previously controlled [25]. At studying the organoleptic quality parameters, there was used the profile estimation method, applied at developing new structures. Its essence is that the complicated notion of one of organoleptic parameters is presented as a totality of simple components, estimated by tasters by quality, intensity and revelation order. The established parameters are considered as main ones, and parameters, cited in SSU are accepted as base ones for projecting the new united characteristic. For further modeling of the quality estimation of all products, all established methods of parameters determination are marked as $\mathrm{P}_{i}$. A verbal characteristic that corresponds to a certain number of points is introduced for each simple component. Characteristics of unitary quality parameters for all products are estimated by the five-point scale. Then the table is formed, and the calculation of the total amount of points of the product is conducted. The obtained data as to determining the unitary parameters is a base of new calculating methods of quality estimation. The new method determines the unitary parameter that allows to reveal a priority of the "studied" sample, comparing to another.

The main advantage of organoleptic analysis as a method of quality estimation of products is a possibility of relatively fast determination of their aptitude for consumption. Such parameters as color, taste, smell, consistence give a general understanding about a product and indicate the correct choice of main ingredients and their ratio.

At the organoleptic estimation at testing the samples, teachers and students of the department determined the outlook, look on a cut, consistence, color, taste and smell of the experimental liver pastes. The organoleptic estimation was conducted by the five-point scale. 
It has been established, that the paste with aubergine powders has the pleasant taste and smell, is rather juicy, with the even color and consistence, typical for this type of products.

\section{Conclusions}

It has been established, that the paste sample is not inferior to traditional products by the sensor parameters, and exceeds them by certain ones (taste, smell, juiciness). Introduction of powders is realized at the stage of homogenization of the paste mass, at that aubergine powder is previously restored. Such introduction method allows to conduct the technological process without changing the main stages of paste production.

Based on the obtained results, it has been established, that the developed technologies of pastes with aubergine powders allows to increase the food and biological value at the expanse of improving the amino acid content of protein, mineral substances by $20 \ldots 70 \%$ - at the expanse of sodium, iron and selenium. At that the caloric content of pastes decreases by $5 \%$ at the background of increasing the total fat amount and decreasing the carbohydrate one.

The offered method of producing pastes with auberdine powder has the following advantages:

- the technological process is not complicated;

- at the lower energetic value, these pastes have the higher biological one, increased content of vitamins, macro- and microelements and food fibers;

- the structural-mechanical properties of the pastes improve;

- the microbiological studies confirms safety of the developed paste.

It must be noted, that the content of such mineral elements as sodium, iron, selenium and iodine in the experimental paste sample is higher than in the control. That is the studies have proved that the paste, obtained by the developed technology, contains the essential amount of vitamins and mineral substances. The use of aubergine powders allows to get the high-quality and safety products, not only rich by the nutrient composition, but also competitive at the expanse of using the cheaper raw materials.

\section{References}

[1] Cherevko, O. I., Peresichnyy, M. I., Peresichna, S. M. (2017). Innovatsiyni tekhnolohiyi kharchovoyi produktsiyi funktsional'noho pryznachennya. Kharkiv: KhDUKhT, 591.

[2] Syrokhman, I. V. (2019). Tovaroznavstvo prodovol'chykh produktiv. Kharkiv: Svit knyh, 713.

[3] Vasyl'yeva, Ya. V. (2013). Pashtety. Farshi. Nachynky. Kharkiv: Arhument Prynt, 256.

[4] Kvasenko, O. I., Kas’yanov, G. I., Aleshkevich, Yu. S., Yushina, Ye. A. (2001). Pat. No. 99115141 RU. Pashtet.

[5] Zdobnov, A. I., Tsyganenko, V. I. (2015). Sbornik retseptur blyud i kulinarnykh izdeliy. Kyiv: Arys, 688.

[6] Dzyundzya, O., Burak, V., Averchev, A., Novikova, N., Ryapolova, I., Antonenko, A. et. al. (2018). Obtaining the powder-like raw materials with the further research into properties of eggplant powders. Eastern-European Journal of Enterprise Technologies, 5 (11 (95)), 14-20. doi: http://doi.org/10.15587/1729-4061.2018.143407

[7] Dzyundzya, O., Burak, V., Averchev, A., Novikova, N., Ryapolova, I., Antonenko, A. et. al. (2018). Investigation of technological properties of powder of eggplants. EUREKA: Life Sciences, 5, 22-29. doi: http://doi.org/10.21303/2504-5695. 2018.00723

[8] Choe, J., Kim, G.-W., Kim, H.-Y. (2019). Effects of green tea leaf, lotus leaf, and kimchi powders on quality characteristics of chicken liver sausages. Journal of Animal Science and Technology, 61 (1), 28-34. doi: http://doi.org/10.5187/jast.2019.61.1.28

[9] Lorenzo, J. M., Domínguez, R., Agregán, R., Gonçalves, A. (2016). Effect of fat replacement by olive oil on the physico-chemical properties, fatty acids, cholesterol and tocopherol content of pâté. Grasas y Aceites, 67 (2), e133. doi: http://doi.org/10.3989/ gya.0629152

[10] Pellegrini, L.-G., Sayas-Barberá, F.-L., Pérez-Álvarez, V.-M. (2018). Quinoa (Chenopodium quinoa Willd) paste as partial fat replacer in the development of reduced fat cooked meat product type pâté: Effect on quality and safety. CyTA - Journal of Food, 16 (1), 1079-1088. doi: http://doi.org/10.1080/19476337.2018.1525433

[11] Domínguez, R., Pateiro, M., Sichetti Munekata, P. E., Bastianello Campagnol, P. C., Lorenzo, J. M. (2016). Influence of partial pork backfat replacement by fish oil on nutritional and technological properties of liver pâté. European Journal of Lipid Science and Technology, 119 (5), 1600178. doi: http://doi.org/10.1002/ejlt.201600178

[12] Zając, M., Świątek, R. (2018). The effect of hemp seed and linseed addition on the quality of liver pâtés. Acta Scientiarum Polonorum Technologia Alimentaria, 17 (2), 169-176. doi: http://doi.org/10.17306/j.afs.0566 
[13] Lucas-González, R., Pellegrini, M., Viuda-Martos, M., Pérez-Álvarez, J. Á., Fernández-López, J. (2018). Persimmon (Diospyros kaki Thunb.) coproducts as a new ingredient in pork liver pâté: influence on quality properties. International Journal of Food Science \& Technology, 54 (4), 1232-1239. doi: http://doi.org/10.1111/ijfs.14047

[14] Shylman, L. Z., Simakova, I. V., Kamsulina, N. V., Fedak, N. V., Obozna, M. V., Bidiuk, D. O. et. al.; Shylman, L. Z. (Ed.) (2016). Zhyry u vyrobnytstvi kharchovoyi produktsiyi. Sumy: Universytetska knyha, 278.

[15] Ivanova, O. V., Kaplina, T. V. (2015). Sanitariia ta hihiiena zakladiv restoranno hohospodarstva. Sumy: Universytetska knyha, 399.

[16] Produktym'yasni. Orhanoleptychne otsinyuvannya pokaznykiv yakosti. Part 2. Zahal'ni vymohy (2007). DSTU 4823.2:2007. Vved. 2009-01-01. Kyiv: Hosstandart Ukrayiny, 14.

[17] Myaso ta myasni produkty. Metod vyznachennya vmistu volohy (kontrol'nyy metod) (ISO 1442:1997. IDT) (2005). DSTU ISO 1442:2005. Vved. 2007-01-01. Kyiv: Derzhavne pidpryyemstvo «Ukrayins'kyy naukovo-doslidnyy i navchal'nyy tsentr problem standartyzatsiyi, sertyfikatsiyi ta yakosti», 6 .

[18] Antypova, L. V. (2001). Metody issledovanyya myasa i myasnykh produktov. Moscow: Kolos, 376.

[19] Fediukyn, V. K., Durnev, V. D., Lebedev, V. H. (2000). Metody otsenky yupravlenyia kachestvom promyshlennoi produktsii. Moscow: Inf. izd. dom «Fylyn», 328.

[20] M'yaso ta m'yasni produkty. Metod vymiryuvannya masovoyi chastky zhyru (2015). DSTU 8380:2015. Vved. 2017-07-01. Kyiv: Derzh spozhyvstandart Ukrayiny, 9.

[21] Vinogradova, A. A., Melkina, G. M., Fomicheva, L. A. et. al. (1991). Laboratornyy praktykum po obshchei tekhnolohyy pyshchevukh proyzvodstv. Moscow: Ahropromyzdat, 335.

[22] Alemasova, A. S., Rokun, A. N., Shevchuk, I. A. (2003). Analiticheskaya atomno-absorbtsionnaya spektroskopiya. Sevastopol: Veber, 327.

[23] Skurykhyn, Y. M. (2007). Tablytsy khymycheskoho sostava i kaloryinosti rossyiskikh produktov pitaniia. Moscow: DeLy, 276.

[24] Dotsyak, V. S. (2014). Tekhnolohiya pryhotuvannya izhi z osnovamy tovaroznavstva prodovol'chykh tovariv. Kyiv: Nash chas, 400 .

[25] Shul'ha, O. S., Chorna, A. I. (2014). Sensornyy analiz. Kyiv: NUKHT, 74.

Received date 11.04.2019

Accepted date 28.05.2019

Published date 31.07.2019
(C) The Author(s) 2019

This is an open access article under the CC BY license (http://creativecommons.org/licenses/by/4.0). 